\title{
Перспективы создания голозерных сортов овса в зоне северной лесостепи Тюменской области
}

\author{
Иванова Ю.С.*, Фомина М.Н., Пай О.А. \\ Научно-исследовательский институт сельского хозяйства Северного Зауралья- \\ филиал Федерального исследовательского ичентра ТюмНЦ СО РАН, пос. Московский, \\ Тюменская область, Россия \\ *e-mail: averyasova-uliy@mail.ru
}

Создание голозерных сортов овса - одно из перспективных направлений селекции в мире. Овес - культура универсальная и широко используется как на кормовые, так и продовольственные цели. Для создания новых сортов голозерного овса необходимо учитывать основные направления: скороспелость, иммунитет, высокое качество зерна, урожайность, технологические и морфологические показатели. В связи с этим проведена оценка 213 голозерных образцов овса различного экологогеографического происхождения. Для включения в селекционный процесс могут быть рекомендованы перспективные образцы, сочетающие высокую продуктивность и скороспелость: к-15014 Левша (Кемеровская область), к-15136 Avenuda (Jakub) (Чехия), к-15137 Detvan (Словакия), к-1926 HUU-LESS (Китай). Выделены источники комплексной устойчивости к пыльной головне, корончатой ржавчине и красно-бурой пятнистости: к-14365 Белорусский голозерный (Белоруссия), к-11663 Caesar (Германия), к-15094 MF9521-247 (США), к-15091 MF9224-336 (США). По биохимическим показателям качества зерна выделен перспективный исходный материал для использования в селекционной практике. В этом плане большой интерес представляют: к-15132 Местный (Франция), к-14944 Местный (Нидерланды), к-2353 Местный (США). Особо следует отметить образец к-2299 Polard (Канада), который наряду с высокими показателями качества формировал достаточно высокий урожай зерна. Выделены источники хозяйственно ценных признаков, которые могут быть рекомендованы для использования в селекции овса голозерного на продовольственные цели: без опушения зерновки - к-2122 Avoine nue grosse (Франция), к-14602 Krypton (Великобритания), к-15305 Gehl (Канада); с низким содержанием пленчатых зерен - к-5321 Местный (Пермский край), к-7439 Местный (Красноярский край), к-14719 Вандроуник (Беларусь), к-15120 Гоша (Беларусь); крупнозерные с высоким содержанием эндосперма к-8427 Местный (Приморский край), к-8739 Голозерный (Мордовия), к-14717 Пушкинский (Ленинградская область), к-14960 Вятский голозерный (Кировская область), к-14227 Бег 2 (Беларусь), к-14182 Нја 76037 N (Финляндия), к-15299 Gkzalon (Монголия). 